\title{
Charleston Draws Record Crowd to the 16th Annual Dysphagia Research Society (DRS) Meeting: President's Report 2008
}

\author{
Bonnie Martin-Harris
}

Published online: 17 September 2008

(C) Springer Science+Business Media, LLC 2008

The Dysphagia Research Society hosted 382 clinical and basic scientists from 27 countries at its 16th annual meeting held at the Wild Dunes Resort, Isle Of Palms in Charleston, SC. Recorded meeting attendance was the largest since the inception of the Society. The 2008 platform featured 79 posters and 47 oral paper presentations and offered diverse research topics reaching across all the disciplines (speechlanguage pathology, otolaryngology, gastroenterology, neurology, neuroscience, radiology, oncology, dental medicine, nursing, developmental pediatrics, gerontology, pulmonary medicine, physical and rehabilitation sciences, engineering, and nutrition) represented at the meeting of the seasoned research society.

The diversity of topics was exceeded only by the 51 highly accomplished members of the program planning committee who took ownership for the collaborative development and resultant success of the meeting. The program was strategically planned to follow the current clinical demand for development of novel diagnostic methods and interventions for dysphagia treatment and with the National Institutes of Health's (NIH) initiatives that focus on bringing together collaborative, interdisciplinary research teams that seek and disseminate new knowledge and interventions for improved patient survival, health, and quality of life. The discipline-diversity of the membership strengthened the science and the relevance of the research hypotheses that were generated from the sessions. Session topics ranged from grappling with relevant

B. Martin-Harris $(\bowtie)$

Evelyn Trammell Institute for Voice and Swallowing, Medical University of South Carolina, 135 Rutledge Avenue, MSC 550, Charleston, SC 29425, USA

e-mail: harrisbm@musc.edu epidemiologic aspects of dysphagia to examination of sensorimotor mechanisms that underlie the functional, physiologic swallowing continuum. Didactic sessions highlighted the challenges associated with signal validity in all aspects of recording swallowing function from the end organ to the cortex. The evidence presented in the sessions underscored the appreciation for the relevance of acrosssystem neural control and consideration of these interactions in the development and testing of novel behavioral, pharmacologic, and surgical interventions for swallowingdisordered patients from development through senescence. Finally, the preconference, attended by a record 189 participants, took on a new premise this year that demonstrated the importance of the researcher-clinician teams as they tackled tough questions in the areas of dysphagia related to head and neck and neurologic disorders-our two most prevalent patient populations who suffer from feeding and swallowing disorders over the age spectrum.

Our seasoned and loyal society members welcomed many new participating interdisciplinary scientists to our meeting who infused a new level of energy in our strategic direction for the study of normal and disordered deglutition. The 2008 DRS meeting was the first in its history to include a focused international research outreach initiative that profiled the work by our off-shore colleagues.

A very special feature of the meeting was the presentation and participation by the renowned gastroenterologist, scientist, educator, mentor, and longstanding friend of the Society, Dr. Donald O. Castell. Dr. Castell, the presenter of the esteemed Dodds-Donner lecture, discussed the clinical importance of nonacid reflux studied with combined impedance-pH monitoring. In keeping with the spirit of mentoring and the mission of the Society that encourages young researchers to achieve independence in their scientific careers, the meeting also included the first New 
Investigator Forum featuring our award-winning young scientists, and a didactic session with some of the Society's most prolific investigators during which they shared their experiences and wisdom on facilitation of mutually successful mentee/mentor relationships.

It cannot be overstated that the success of the meeting required a great deal of support from many people. The Board and I wish to extend our sincere appreciation for the generous support provided by our industry partners. The participation of new and historically faithful allies speaks to their commitment to moving our science forward and to assisting the Society in meeting the rising financial challenges associated with planning these events. Most importantly, we extend our gratitude to every participant at the meeting who devoted their valuable time, prioritized their often limited continuing educational dollars, and sacrificed their own personal finances in order to attend the 2008 DRS meeting.

\section{Board of Directors}

President Bonnie Martin-Harris, PhD, CCC-SLP, BRS-S

President-Elect Benson T. Massey, MD, FACP

Secretary-Treasurer Gregory N. Postma, MD

Past President Arthur J. Miller, PhD

\section{Councilors}

Rebecca Z. German, PhD

Cathy L. Lazarus, PhD, CCC-SLP, BRS-S

Douglas J. Van Daele, MD

Eiichi Saitoh, MD, DMSc

John C. Rosenbek, PhD, CCC-SLP

\section{Program Committee}

Bonnie Martin-Harris, PhD, CCC-SLP, BRS-S, Chair Joan Arvedson, PhD, CCC-SLP, BRS-S

Hans Bogaardt, MSc

Marion Boyd Gillespie, MD

Martin B. Brodsky, PhD, CCC-SLP

Margareta Ch. Bülow, PhD, SLP

Susan G. Butler, PhD, CCC-SLP

Giselle D. Carnaby-Mann, MPH, PhD

Donald O. Castell, MD

Nadine P. Connor, PhD, CCC-SLP

Ian J. Cook, MBBS, MD(Syd), FRACP

Michael A. Crary, PhD, CCC-SLP

Stephanie K. Daniels, PhD, CCC-SLP, BRS-S

Terry Day, MD
Caryn S. Easterling, PhD, CCC, BRS-S

Olle Ekberg, MD

Rebecca Z. German, PhD

Eugene C. Goldfield, PhD

Lucinda A. Halstead, MD

Shaheen Hamdy, MB ChB, PhD, FRCP

Maggie-Lee Huckabee, $\mathrm{PhD}$

Bronwyn Jones, MD, FRACP, FRCR

Peter J. Kahrilas, MD

Lisa N. Kelchner, PhD, CCC-SLP, BRS-S

Ivan M. Lang, DVM, PhD

Susan E. Langmore, PhD, CCC-SLP, BRS-S

Cathy L. Lazarus, PhD, CCC-SLP, BRS-S

Maureen A. Lefton-Greif, PhD, CCC-SLP, BRS-S

Jeri A. Logemann, PhD, CCC-SLP, BRS-S

Christy L. Ludlow, PhD, CCC-SLP

Linda Mackay, MA, CCC-SLP, BRS-S

Ruth E. Martin, PhD, MHSc

Rosemary Martino, MA, MSc, PhD

Benson T. Massey, MD, FACP

Timothy M. McCulloch, MD

Gary H. McCullough, PhD, CCC-SLP

Arthur J. Miller, PhD

Ravinder K. Mittal, MD

Mark A. Nicosia, PhD

Jeffrey B. Palmer, MD

Adrienne L. Perlman, PhD, CCC-SLP, BRS-S

Gregory N. Postma, MD

Maxine Power, $\mathrm{PhD}$

JoAnne Robbins, PhD, CCC-SLP, BRS-S

John C. Rosenbek, PhD, CCC-SLP

Colin D. Rudolph, MD, PhD

Eiichi Saitoh, MD, DMSc

Reza Shaker, MD

Barbara C. Sonies, PhD, CCC-SLP, BRS-S

Catriona M. Steele, PhD, S-LP(C), CCC-SLP

Brad P. Sutton, PhD

Douglas J. Van Daele, MD

David E. White, MD

Anita Wuttge-Hanning, MD

\section{DRS Award Winners}

Cathy Pelletier, $\mathrm{PhD}$

First Place Award for the DRS Scientific Abstract Oral Presentations: The Effect of Chemesthesis on Lingual Pressure Given Age and Genetic Taste Differences in Healthy Adult Women

Pere Clavé, $\mathrm{MD}, \mathrm{PhD}$

Second Place for the DRS Scientific Abstract Oral Presentations: Selective Stimulation of Excitatory and 
Inhibitory Motor Neurons in Porcine Lower Esophageal Sphincter

Jacqueline Hind, MS, CCC-SLP, BRS-S

Third Place for the DRS Scientific Abstract Oral Presentations: Interobserver Agreement of Videofluoroscopic Measures from a Randomized Clinical Trial

Shanmugam Murugappan, MD

First Place for the Scientific Abstract Poster Presentations: Acoustic and Aerodynamics Mechanisms of Wet Voice

Erin Redle, $\mathrm{PhD}$

Second Place for the Scientific Abstract Poster Presentations: Development of the Pediatric Feeding and Swallowing Disorders Family Impact Scale (PFSDFIS)

Irene Netto, MS

Third Place for the Scientific Abstract Poster Presentations: Prevalence and Perturbation Degree of Long-Term Upper Airway Symptoms After Thyroidectomy With and Without Intraoperative Nerve Monitoring

Erin Yeates, MHSc

ASHA Division 13 Grant: A Preliminary Investigation of the Impact of Tongue Pressure Generation Exercises on Bolus Control
Katherine Hutcheson, MS, CCC-SLP

Won the Yul Brynner Grant: Swallowing Outcomes after Induction Chemotherapy with Targeted Molecular Therapy and Radiotherapy for Advanced Stage Head and Neck Cancer

Georgia Malandraki, MA

First Place for the New Investigators Award for her presentation: Neural Activation of Swallowing and Swallowing-Related Tasks In Healthy Young Adults

Sebastian Doeltgen, MSLT

Second Place for the New Investigators Award for his presentation: Effects of Event-Related Electrical Stimulation On Motor Evoked Potentials at the Submental Muscle Group

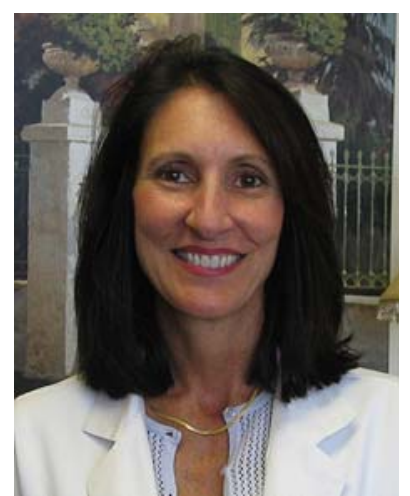

Bonnie Martin-Harris $\mathrm{PhD}$, CCC-SLP, BRS-S 